Volume. 3 Nomor. 2

Periode: Juli - Desember 2019; hal. 47-54

p-ISSN : 2580-1112; e-ISSN : 2655-6669

Copyrighr @2019

Penulis memiliki hak cipta atas artikel ini

Jurnal Ilmiah Keperawatan Orthopedi

(JIKO)

journal homepage: https://ejournal.akperfatmawati.ac.id

\title{
Pelaksanaan Pengukuran Tanda-Tanda Vital Pada Pasien Sirosis Hepatis Untuk Mencegah Hipertensi Portal
}

\author{
Zahri Darni ${ }^{1}$, Siti Rahmah ${ }^{2}$ \\ Akademi Keperawatan Fatmawati, Jakarta
}

\begin{abstract}
Abstrak
Sirosis hepatis adalah penyakit progresif kronis yang ditandai oleh inflamasi, fibrosis dan degenerasi sel-sel parenkim hati yang berlangsung terus-menerus yang akan mengakibatkan obstruksi sirkulasi portal hepatis dan gagal fungsi hepar. Hati menjadi rusak dan mengeras menyebabkan tekanan pada vena portal meningkat dan mengakibatkan terjadinya hipertensi portal sehingga timbul hemostatis vaskuler dan varises esofagus. Apabila tidak ditangani varises esofagus pecah sehingga terjadi perdarahan dan timbul hematemesis melena. Tindakan pencegahan yang dapat dilakukan oleh perawat adalah mengukur tanda-tanda vital. Tanda-tanda vital adalah cara yang cepat dan efisien untuk memantau kondisi pasien atau mengidentifikasi masalah dan mengevaluasi respon pasien terhadap intervensi. Penelitian ini bertujuan untuk mendapatkan gambaran pelaksanaan pengukuran tanda-tanda vital pada pasien sirosis hepatis untuk mencegah hipertensi portal di RSUP Fatmawati. Metode penelitian yang digunakan yaitu deskriptif dengan pendekatan studi kasus (dua kasus) dan menggunakan teknik pengumpulan data dengan wawancara, observasi, dan studi dokumentasi. Hasil penelitian pada studi kasus ini adalah risiko injuri: perdarahan tidak terjadi yang menunjukkan pasien tidak mengalami hipertensi portal. Penelitian ini merekomendasikan agar perawat dapat melakukan pemeriksaan tanda-tanda vital yang baik dan tepat sehingga hipertensi portal dapat dicegah.
\end{abstract}

Kata Kunci: Hipertensi Portal, Sirosis Hepatis, Tanda-Tanda Vital

\begin{abstract}
Hepatic cirrhosis is a chronic progressive disease characterized by inflammation, fibrosis and degeneration of liver parenchymal cells that persist which will result in obstruction of the portal circulatory hepatic and liver failure. The liver becomes damaged and hardens causing pressure on the portal vein to increase and result in portal hypertension and resulting in the emergence of vascular hemostatis, and esophageal varices. Esophageal varices if not treated can be rupture resulting in bleeding and hematemesis melena arises. The preventive action that a nurse can take is to measure vital signs. Vital signs are a fast and efficient way to monitor client conditions or identify problems and evaluate client responses to interventions. This study aims to get an overview of the implementation of measuring vital signs in patients with hepatic cirrhosis to prevent portal hypertension in Fatmawati General Hospital. The case study method used is descriptive with two cases by using interview, observation, and documentation
\end{abstract}

\footnotetext{
1,2 e-mail: zahri.darni@akperfatmawati.ac.id
} 
study techniques. The results of the study in this case study were the risk of injury: bleeding did not occur indicating patients did not experience portal hypertension. This case study recommends that nurses be able to check vital and proper signs so that portal hypertension can be prevented.

\section{Keywords: Hepatic Cirrhosis, Portal Hypertension, Vital Signs}

\section{Pendahuluan}

Pola hidup modern yang dianggap trend menjadi pemicu untuk negara berkembang untuk meniru kebiasaan serta trend yang ada di negara maju, contohnya adalah dengan meminum alkohol yang dijadikan sebagai suatu gaya hidup yang dapat dijadikan untuk menghilangkan penyebab stress dalam hidup.

Mengkonsumsi alkohol dalam waktu yang lama akan menyebabakan timbul penyakit salah satunya sirosis hepatis (Bauldoff, Burke, \& LeMone, 2017). Menurut Condreng (2014), dalam jurnal $e$-Clinic, alkohol merupakan risiko terbesar dari sekitar 60 jenis penyakit dan merupakan faktor komponen dari 200 jenis penyakit lainnya, salah satunya adalah gangguan fungsi hati yaitu sirosis hepatik.

Sirosis hepatik adalah penyakit kronis yang menyebabkan destruksi sel dan fibrosis (jaringan parut) dari jaringan hepatis. Fibrosis mengubah struktur dan vaskularisasi normal hati, merusak aliran darah dan limfe serta mengakibatkan insufisiensi hepatik dan hipertensi vena portal (Nettina S, 2002).

Secara histologi, sirosis hepatis didefinisikan sebagai proses difusi yang ditandai oleh fibrosis dan perubahan arsitektur hepar yang normal menjadi struktur hepar yang abnormal (bernodul). Perubahan struktur tersebut terjadi akibat cedera pada sel hepar sehingga terjadi penghancuran hepatosit dan diganti dengan jaringan parut. Jaringan parut ini menggantikan parenkim hepar yang normal (Berman S, 2010).

Etiologi yang ditemukan dari penyakit sirosis hepatik selain penggunaan alkohol jangka panjang antara lain dapat disebabkan oleh hepatitis kronis tipe $\mathrm{B}, \mathrm{C}$, dan $\mathrm{D}$, penyakit hepar metabolik seperti hemokromatosis dan penyakit Wilson; penyakit hepar kolestasis serta pemakaian obat seperti isoniazid, metildopa, estrogen, dan steroid. Infeksi hepatitis $\mathrm{C}$ adalah penyebab terbanyak terjadinya sirosis hepatik di Amerika dan diikuti karena alcoholic liver disease. Penyebab lainnya adalah faktor genetik, hepatitis B, hepatitis D, Non Alcoholic Fatty Liver Disease (NAFLD) dan obatobatan (Berman S, 2010).

Sirosis hepatis menempati urutan ke-7 penyebab kematian di dunia. Sekitar 25.000 orang meninggal setiap tahun akibat penyakit ini (Simamora, 2013). Sirosis juga menempati urutan ke-12 penyebab utama kematian di Amerika. Lebih dari 26.000 kematian setiap tahun di Amerika disebabkan oleh penyakit ini (Sease et al, 2008).

Di Asia Tenggara, prevalensi penderita sirosis hepatis terbanyak terjadi pada kaum pria dengan rata-rata usia 45 sampai 69 tahun (Anindita, 2013). Di Indonesia, penyakit ini cukup banyak ditemukan. Sekitar $50 \%$ pasien yang dirawat di ruang penyakit dalam RSUPN dr. Cipto Mangunkusumo pada periode bulan Juni sampai dengan November 2004 terdapat 69 pasien laki-laki dan 39 pasien perempuan sirosis, terbanyak pada rentang umur 45-54 tahun (WHO, 2014).

Manifestasi klinis dari sirosis antara lain asites, hipertensi portal, perdarahan varises, hepatik ensefalopati, dan gangguan koagulasi. Salah satu manifestasi yang paling serius dan membahayakan hidup pasien sirosis hepatis adalah terjadinya perdarahan varises esofagus. 
Pada pasien sirosis hepatis, jaringan ikat dalam hepar menghambat aliran darah dari hepar ataupun usus yang kembali ke jantung. Kejadian ini dapat mengakibatkan peningkatan tekanan dalam vena porta (hipertensi portal). Sebagai hasil peningkatan aliran darah dan peningkatan tekanan porta ini, venavena di bagian bawah esofagus dan bagian atas lambung akan melebar, sehingga timbul varises esofagus. Makin tinggi tekanan portalnya, makin besar varisesnya, dan apabila varisesnya pecah, maka pasien akan mengalami perdarahan (variceal bleeding) (Berman S, 2010).

Resiko kematian yang tinggi pada pasien sirosis hepatis yang mengalami manifestasi hipertensi portal dapat menyebabkan perdarahan varises esofagus. Perdarahan yang timbul akibat varises esofagus tersebut sangat membutuhkan peran perawat dalam melakukan tindakan pencegahan dengan membantu pasien dalam proses pengobatan.

Fokus utama pengobatan umumnya ditujukan untuk pencegahan hipertensi portal, salah satunya adalah pemberian terapi farmakologi diantaranya obat-obat penyekat beta (beta bloker) yang digunakan secara oral contohnya adalah propanolol. Propanolol adalah penghambat adrenergik-beta, seringkali disebutkan sebagai beta, yaitu menurunkan rangsangan hormon adrenalin yang menyebabkan denyut jantung menurun sehingga frekuensi nadi menurun sehingga tindakan yang dapat dilakukan oleh perawat adalah observasi tanda-tanda vital.

Menurut hasil penelitian Farida Y. dan Ratnasari N. (2014), pada kondisi pasien yang mengalami perbaikan dengan terapi standar dilakukan modifikasi terapi seperti pada kasus perdarahan dengan menambahkan proton pump inhibitor (omeprazole, lansoprazol atau pantoprazole, propanolol) dan asam traneksamat. Menurut Herdiman, Sugiarto, dan Widjaja (2014), hubungan tekanan darah sistolik dengan jumlah trombosit memiliki nilai signifikan $p=0,002$ dan spearman's $=0,467$. Hubungan tekanan darah diastolik dengan kadar hematokrit memiliki signifikan $\quad p=0,035 \quad$ dan spearman's $=0,467$.

Tujuan penelitian ini adalah untuk mendapatkan gambaran pelaksanaan pengukuran tanda-tanda vital pada pasien sirosis hepatis untuk mencegah hipertensi portal di RSUP Fatmawati.

\section{Metode Penelitian}

Metode penelitian ini adalah deskriptif dengan pendekatan studi kasus untuk mengambarkan pelaksanaan pengukuran tanda-tanda vital pada pasien sirosis hepatis untuk mencegah hipertensi portal. Penelitian ini menggunakan sample yang terdiri dari dua pasien/kasus.

Kriteria inklusi penelitian ini adalah: tingkat kesadaran pasien compos mentis, pasien dengan pemberian terapi propanolol, mempunyai data lengkap dan tercatat di file rekam medis. Kriteria eksklusi penelitian ini adalah: pasien dengan penyakit bukan sirosis hepatis, tingkat kesadaran pasien tidak compos mentis, pasien dengan tidak mendapatkan pemberian terapi propanolol, dan tidak mempunyai data lengkap dan tercatat di file rekam medis.

Metode pengumpulan data dengan wawancara, observasi dan studi dokumentasi. Instrumen penelitian dengan menggunakan format pengkajian Keperawatan Medikal Bedah (KMB). Lokasi penelitian adalah di Lantai VI Utara Instalasi Teratai RSUP Fatmawati. Waktu penelitian pada bulan Maret 2019. Analisis data dalam penelitian ini akan dijelaskan sesuai dengan jumlah indikator yang akan diteliti yang telah peneliti tetapkan pada instrumen penelitian tentang tanda-tanda vital yang meliputi: tekanan darah, nadi, suhu, dan pernapasan. Sebelum melaksanakan penelitian ini peneliti memberikan 
lembar informed consent kepada pasien untuk mendapatkan persetujuan untuk diteliti.

\section{Hasil Penelitian \\ Kasus 1}

Pasien berusia 60 tahun berasal dari suku Betawi, beragama Islam, pendidikan terakhir SD, pekerjaan Ibu rumah tangga, pasien tinggal di $\mathrm{Jl} . \mathrm{H}$. Muslim No. 62 RT 007/RW10 Pondok Labu, Jakarta Selatan. Pasien masuk RSUP Fatmawati pada tanggal 24 Febuari 2019 di HCU dan masuk ke ruangan VI Utara tanggal 03 Maret 2019 dengan diagnosa medis sirosis hepatis dan riwayat melena. Keluhan utama: pasien mengatakan pusing, lemas, perut terasa penuh dan membesar. Pasien mempunyai riwayat hipertensi sejak 2010. Pasien kontrol apabila ada keluhan pusing ke klinik dekat rumah dan mendapatkan obat amlodipine $1 \times 10 \mathrm{mg}$ secara rutin tetapi pasien tidak patuh minum obat. Pasien pernah dirawat dan mempunyai riwayat melena tahun 2012 dan minum obat propanolol $3 \times 10 \mathrm{mg}$ tetapi tidak rutin minum obat. Pasien mengatakan keluarganya memiliki sirosis hepatis yaitu suami dan menantunya.

Berat badan sebelum sakit $62 \mathrm{~kg}$, berat badan saat ini $60 \mathrm{~kg}$ dengan tinggi badan $150 \mathrm{~cm}$. irama nadi teratur, tingkat kesadaran composmentis, temperatur kulit dingin, warna kulit pucat, konjungtiva anemis, sklera ikterik. Tidak ada edema pada tungkai atas maupun bawah. Pasien mengatakan tidak mual dan tidak ada muntah, bising usus pasien $9 \mathrm{x} /$ menit, pasien mengalami konstipasi (3 hari belum buang air besar), abdomen asites dan tegang.

Hasil pemeriksaan laboratorium, $\mathrm{Hb}: 11.0$ g/dl (13.2-17.3), Ht: $30 \%$ (3345\%), Eritrosit: 3,49 juta/ul (4.40-5.90), Albumin: $2,60 \mathrm{~g} / \mathrm{dl}(3,40-4,80)$, Klorida (darah): $110 \mathrm{mmol} / \mathrm{l}$ (95-108). Hasil USG abdomen: sirosis hepatis dengan micronoduler lesi dan asites massif disertai splenomegali ringan. Contracted gall bladder dengan cholelithiasis dan cystitis. Organ-organ lain dalam batas normal. Penatalaksanaan: Amlodipine $10 \mathrm{mg} / 24$ jam, Propanolol 10/8 jam, Vipalbumin 1 gram/8 jam, Omeprazole $40 \mathrm{mg} / 12$ jam via IV bolus, diet hati 2 diet lunak.

\section{Kasus 2}

Pasien berusia 36 tahun berasal dari suku Jawa, beragama Islam, dan pendidikan terakhir SLTP. Pasien sebelumnya bekerja sebagai buruh pabrik cat, klien tinggal di Jl. Mandor Tajir Rt 002/Rw 06 Depok. Pasien masuk RSUP Fatmawati tanggal 12 Maret 2019 dengan diagnosa medis sirosis hepatis ecausa hepatitis B. Keluhan utama, pasien mengatakan pusing, lemas, tidur terganggu. Pasien mempunyai penyakit hepatitis B tahun 2016 dan pernah mengalami hematemesis melena tahun 2018 dan mendapatkan obat propanolol $3 \times 10 \mathrm{mg}$ dan rutin minum obat setiap hari. Pasien mengatakan tidak ada dari keluarganya yang memiliki penyakit yang sama dengan pasien.

Berat badan sebelum sakit $60 \mathrm{~kg}$, berat badan saat ini $59 \mathrm{~kg}$ dengan tinggi badan $165 \mathrm{~cm}$. Irama nadi teratur, tingkat kesadaran composmentis, temperatur kulit hangat, warna kulit ikterik dan pucat, konjungtiva anemis, sklera ikterik, tidak ada edema pada tungkai atas maupun bawah, tidak ada muntah, bising usus $11 \mathrm{x} /$ menit, pasien tidak diare, konstipasi, BAB hitam, abdomen pasien lembek.

Hasil pemeriksaan laboratorium, $\mathrm{Hb}: 5,9$ g/dl (13.2-17.3), Ht: $23 \%$ (3345\%), leukosit: 2,0 ribu/ul (5.0-10.0), Eritrosit: 3,53 juta/ul (4.40-5.90), Trombosit: 66 ribu/ul (150-440), PT: 16,3 detik (11,5-14,5 detik). Hasil EEG: Varises esofagus potensial berdarah. Gastropati hipetrensi portal. Penatalaksanaan: propanolol 10/8 jam, Omeprazole $20 \mathrm{mg} / 12$ jam, Spirorolceton $100 \mathrm{mg} / 24$ jam, diet hati 2 diet lunak. 
Pengkajian tanda-tanda vital

Dalam studi kasus ini pengkajian awal yang dilakukan berfokus pada tanda-tanda vital pasien.

Tabel 1 Pengkajian awal

Tanda-tanda

\begin{tabular}{ll} 
vital & \multicolumn{2}{c}{ Kasus } \\
\cline { 2 - 3 } Awal & Kasus 1 \\
\hline
\end{tabular}

Tekanan

darah $\quad 140 / 79 \mathrm{mmHg} \quad 96 / 62 \mathrm{mmHg}$

Nadi $\quad 96 \mathrm{x} /$ menit $\quad 81 \mathrm{x} / \mathrm{menit}$

Pernapasan $21 \mathrm{x} /$ menit $18 \mathrm{x} /$ menit

\begin{tabular}{lll}
\hline Suhu & $36,8^{\circ} \mathrm{C}$ & $36,5^{\circ} \mathrm{C}$
\end{tabular}

Berdasarkan table 1 diketahui bahwa hasil tekanan darah kasus 1 adalah 140/79 $\mathrm{mmHg}$, nadi adalah 96 $\mathrm{x} /$ menit, respirasi adalah $21 \mathrm{x} / \mathrm{menit}$, dan suhu $36,8^{\circ} \mathrm{C}$ dan pada kasus 2 tekanan darah adalah 96/62 $\mathrm{mmHg}$, nadi adalah $81 \mathrm{x} /$ menit, pernapasan adalah 18 $\mathrm{x} /$ menit, dan suhu $36,5^{\circ} \mathrm{C}$.

\section{Diagnosa Keperawatan}

Dari data gambaran studi kasus hasil pengukuran tanda-tanda vital diagnosa keperawatan yang peneliti rumuskan yaitu risiko injuri: perdarahan berhubungan dengan profil darah abnormal: gangguan faktor pembekuan (penurunan produksi protrombin, fibrinogen dan faktor VIII, IX dan X, gangguan absorbs vitamin $\mathrm{K}$, dan pengeluaran tromboplastin), serta hipertensi portal.

Perencanaan dari diagnosa keperawatan tersebut salah satunya adalah pengukuran tanda-tanda vital yang akan peneliti observasi atau lakukan dalam 4 hari. Pengukuran tanda-tanda vital ini dilakukan dalam $3 x$ /hari sesudah pemberian terapi propanolol.Tujuan propanolol adalah penghambat adrenergik-beta, seringkali disebutkan sebagai beta, yaitu suatu obat yang berfungsi untuk menurunkan rangsangan hormon adrenalin yang menyebabkan denyut jantung menurun sehingga frekuensi nadi menurun, yang biasanya digunakan pada pasien hipertensi, angina pektoris, bahkan hipertensi portal.
Sebelum peneliti melakukan tanda-tanda vital, peneliti akan memberikan edukasi tentang perawatan penyakit pada pasien sirosis dengan menggunakan lembar balik dan leaflet serta dihadiri oleh keluarga pasien.

Pelaksanaan tindakan keperawatan ini peneliti dapat melakukan sesuai rencana. Pada hari pertama yang telah peneliti lakukan adalah penyuluhan kesehatan yang dihadiri oleh keluarga, pada kasus 1 dihadiri oleh anak pasien dan pada kasus 2 dihadiri oleh istri pasien. Penyuluhan kesehatan berlangsung dengan baik, keluarga tampak koperatif hal ini dibuktikan pada saat edukasi masing-masing keluarga baik kasus 1 dan kasus 2 bertanya dan kemudian mengukur tanda-tanda vital. Hari kedua peneliti mengukur tandatanda vital serta berkoordinasi dengan perawat ruangan. Hari ketiga setelah peneliti mendapatkan hasil tanda-tanda vital, peneliti menganjurkan pasien untuk minum obat secara rutin dan tetap mengkonsumsi diet yang diberikan dan mengukur tanda-tanda vital sesudah pemberian terapi propanolol.

$$
\text { Evaluasi pada diagnosa }
$$

keperawatan risiko injuri: perdarahan berhubungan dengan profil darah abnormal: gangguan faktor pembekuan (penurunan produksi protrombin, fibrinogen dan faktor VIII, IX dan X, gangguan absorbsi vitamin $\mathrm{K}$, dan pengeluaran tromboplastin), serta hipertensi portal didapatkan hasil:

Tabel-2 Hasil Tekanan Darah

Tekanan

darah (mmHg)

\begin{tabular}{llll}
\hline Kasus 1 & $150 / 80$ & $149 / 75$ & $153 / 80$ \\
\hline Kasus 2 & $105 / 72$ & $109 / 75$ & $110 / 60$ \\
\hline
\end{tabular}

Berdasarkan table-2 hasil tekanan darah kasus 1 pada hari pertama maupun ketiga mengalami peningkatan pada sebelum dan sesudah pemberian propanolol, pada saat itu kasus 1 merasakan pusing dan peneliti telah 
menganjurkan pasien untuk istirahat dan berkoordinasi dengan perawat ruangan. Pada kasus 2 tekanan darah pasien mengalami peningkatan sesudah pemberian propanolol tetapi kasus 2 tidak terdapat keluhan apapun.

Tabel-3 Hasil Frekuensi nadi

\begin{tabular}{llll}
\hline $\begin{array}{l}\text { Frekuensi nadi } \\
\text { (x/menit) }\end{array}$ & $\begin{array}{l}\text { Hari } \\
\text { ke 1 }\end{array}$ & $\begin{array}{l}\text { Hari } \\
\text { ke2 }\end{array}$ & $\begin{array}{l}\text { Hari } \\
\text { ke 3 }\end{array}$ \\
\hline Kasus 1 & 99 & 99 & 97 \\
\hline Kasus 2 & 82 & 84 & 82 \\
\hline
\end{tabular}

Berdasarkan table-3 frekuensi nadi pada kasus 1 didapatkan mengalami peningkatan, tetapi dalam batas normal pada hari ke 199 x/menit. Hari ke-2 99 $\mathrm{x} /$ menit, hari ke-3 $97 \mathrm{x} /$ menit dan pada kasus 2 pada hari ke- $182 \mathrm{x} /$ menit, hari ke-2 $84 \mathrm{x} /$ menit, hari ke-3 $82 \mathrm{x} / \mathrm{menit}$.

Tabel-4 Hasil Frekuensi Pernapasan

Frekuensi

pernapasan Hari ke 1 Hari ke 2 Hari ke 3 (x/menit)

\begin{tabular}{llll}
\hline Kasus 1 & 19 & 18 & 20 \\
\hline Kasus 2 & 18 & 19 & 18 \\
\hline
\end{tabular}

Berdasarkan tabel-4 hasil pengukuran pernapasan pada kasus 1 hari pertama yaitu $19 \mathrm{x} / \mathrm{menit}$, hari ke-2 18 $\mathrm{x} /$ menit, hari ke-3 $20 \mathrm{x} / \mathrm{menit}$. Frekuensi pernapasan pada kasus 2 pada hari ke-1 yaitu $18 \mathrm{x} /$ menit, hari ke-2 $19 \mathrm{x} / \mathrm{menit}$, hari ke-3 x/menit. Pada Kasus 1 terlihat adanya peningkatan frekunesi pernapasan pada hari pertama dan ketiga tetapi tidak adanya sesak atau napas dalam (pernapasan masih dalam batas normal). Frekuensi pernapasan kasus 2 tidak terjadi peningkatan pada pernapasan.

Tabel-5 Hasil Suhu Tubuh

\begin{tabular}{lllll}
\hline Suhu $\left({ }^{0} \mathrm{C}\right)$ & Hari ke 1 & Hari ke 2 & Hari ke 3 \\
\hline Kasus 1 & 36,5 & 36,7 & 36,9 \\
\hline Kasus 2 & 36,9 & 36,9 & 36,5 \\
\hline
\end{tabular}

Berdasarkan table-5 hasil pengukuran suhu tubuh dari hari pertama pada kasus 1 didapatkan hasil $36,5^{\circ} \mathrm{C}$, pada hari ke-2 $36,7^{\circ} \mathrm{C}$, pada hari ke-3 $36,9^{0} \mathrm{C}$. Kasus 2 pada hari pertama $36,9^{0} \mathrm{C}$, pada hari ke-2 $36,9^{0} \mathrm{C}$, pada hari ke-3 $36,5^{\circ} \mathrm{C}$. Suhu tubuh pada kasus 1 dan kasus 2 pada hari pertama hingga ketiga didapatkan dalam rentang normal $\left(36,5^{0} \mathrm{C}-37,0^{0} \mathrm{C}\right)$.

\section{Pembahasan}

Hasil evaluasi table-2 tentang tekanan darah. Didapatkan hasil tekanan darah kasus 1 selama tiga hari penelitan selalu tinggi dibanding kasus 2 dengan tekanan darah yang normal. Pada kedua kasus tersebut pasien mendapatkan terapi yang sama yaitu propanolol 3x10 mg.

Fungsi propanolol tersebut adalah penghambat adrenergik-beta, seringkali disebut sebagai beta, yaitu menurunkan rangsangan hormon adrenalin yang menyebabkan denyut jantung menurun sehingga frekuensi nadi menurun, yang biasanya digunakan pada pasien hipertensi, angina pektoris, bahkan hipertensi portal. Dengan pemberian propanolol diharapkan tekanan darah pasien normal.

Faktor lain yang menyebabkan tekanan darah pada pasien kasus 1 selalu tinggi meskipun sudah mendapatkan propanolol adalah usia, dikarenakan usia pada kasus 1 lebih tua dibandingkan kasus 2. Faktor keturunan, kasus 1 memiliki riwayat hipertensi sejak 2010. Menurut Marliani, Lili, dan Tantan (2007), menjelaskan bahwa semakin bertambah usia maka tekanan darah akan meningkat karena elastisitas pembuluh darah menurun.

Faktor keturunan yang mempengaruhi curah jantung, volume darah, viskositas darah dan atau komplikasi arteri akan berdampak langsung pada tekanan darah. Dengan ditemukan tekanan darah pada pasien kasus 1 yang masih tinggi perlu diwaspadai oleh perawat untuk dikolaborasikan dengan dokter terhadap dosis yang akan ditetapkan. 
Dari hasil evaluasi table-3 tentang nadi. Didapatkan hasil nadi kasus 2 selama tiga hari penelitian selalu normal dibanding kasus 1 dengan nadi yang tinggi. Pada kedua kasus tersebut pasien mendapatkan terapi yang sama yaitu propanolol 3x10 mg.

Fungsi propanolol tersebut adalah menurunkan tekanan darah tinggi, sakit kepala atau migran, dan hipertensi portal yang dapat berguna untuk menurunkan tekanan darah dan nadi. Dengan pemberian propanolol diharapkan nadi pasien normal.

Faktor lain yang menyebabkan nadi pada kasus 2 selalu normal adalah usia dan jenis kelamin. Menurut Safitri dan Dwi (2017), menjelaskan bahwa jenis kelamin seseorang akan mempengaruhi kecepatan nadi karena pada jenis kelamin laki-laki nadi kerja mencapai 128 denyut permenit, sedangkan wanita 138 denyut permenit. Dengan ditemukan nadi pada pasien kasus 1 yang masih tinggi perlu diwaspadai oleh perawat untuk dikolaborasikan dengan dokter terhadap dosis yang akan ditetapkan.

Menurut Kee, Joyce \& Hayes, Evelyn (2006), propanolol adalah penghambat adrenergik-beta, seringkali disebutkan sebagai beta, yaitu menurunkan rangsangan hormon adrenalin yang menyebabkan denyut jantung menurun sehingga frekuensi nadi menurun, yang biasanya digunakan pada pasien hipertensi, angina pectoris, bahkan hipertensi portal, dibanding kasus 1, hal ini disebabkan disamping pasien mendapatkan propanolol yang berfungsi untuk menangani tekanan darah tinggi, sakit kepala atau migran, dan hipertensi portal yang dapat berguna unuk menurunkan tekanan darah dan nadi, juga latar belakang pendidikan serta kepatuhan pasien kasus 2 terhadap pengobatan yang telah diberikan.

Hasil evaluasi table-4 dan table-5 tentang pernapasan dan suhu. Hasil pengukuran pernapasan dan suhu menunjukkan hasil normal, hal ini disebabkan pada pasien sirosis hepatis untuk mencegah terjadinya hipertensi portal pernapasan dan suhu tidak terlalu berhubungan. Hal ini dibuktikan dalam jurnal Dianne, Hernofialdi, dan Sayoeti (2007), sepertiga dari kasus sirosis hepatis menunujukkan demam tetapi jarang lebih dari $37,5^{\circ} \mathrm{C}$ dan pernapasan tidak lebih dari $20 \mathrm{x} /$ menit.

\section{Kesimpulan}

Berdasarkan hasil penelitian pelaksanaan pengukuran tanda-tanda vital pada kedua pasien sirosis hepatis untuk mencegah hipertensi portal yang dirawat di Instalasi Teratai Lantai VI Utara RSUP Fatmawati Jakarta tahun 2019 peneliti mengambil kesimpulan bahwa kasus 1 dan kasus 2 risiko injuri: perdarahan tidak terjadi yang menunjukkan pasien tidak mengalami hipertensi portal dengan melakukan pengukuran tanda-tanda vital hari pertama sampai hari ketiga.

Hasil pengukuran tekanan darah pada kasus 1 di hari pertama sampai hari ketiga mengalami peningkatan dibandingkan kasus 2 tetapi kasus 1 tidak mengalami dampak yang serius seperti terjadinya hipertensi portal, hal ini disebabkan oleh adanya faktor-faktor yang mempengaruhi tekanan darah seperti kasus 1 dengan usia lebih tua dibandingkan kasus 2 dan faktor keturunan, kasus 1 memiliki riwayat hipertensi sejak 2010 dan tidak pernah rutin untuk minum obat.

Frekuensi nadi kasus 2 selalu normal pada hari pertama hingga hari ketiga dibandingkan pada kasus 1 , hal ini disebabkan oleh adanya faktor-faktor yang mempengaruhi frekuensi nadi seseorang seperti, usia kasus 2 lebih muda dibandingkan kasus 1 dan jenis kelamin, kasus 2 dengan jenis kelamin laki-laki menunjukkan nadi yang lebih rendah dibandingkan kasus 1 yang memiliki jenis kelamin perempuan, akan tetapi peneliti tidak menemukan keluhan 
pada kasus 1 yang serius selama melakukan penelitian.

Pernapasan/respirasi dan suhu pada kasus 1 dan kasus 2 pada hari pertama sampai hari ketiga menunjukan hasil pengukuran tidak mengalami peningkatan atau penurunan hal ini disebabkan pada pasien sirosis hepatis untuk mencegah terjadinya hipertensi portal pernapasan dan suhu tidak terlalu berhubungan.

\section{Daftar Pustaka}

Amalina, H.A., dan Kriswiastiny, R. (2017). Perdarahan saluran cerna bagian atas karena sirosis hepatis. Journal Medula Unila. Vol. 4. No. 2.

http://juke.kedokteran.unila.ac.id/ar ticle/view

Baradero, M (2008). Klien gangguan hati: seri asuhan keperawatan: Jakarta: EGC

Doenges, M. (2018). Rencana asuhan keperawatan : pedoman untuk perencanaan dan pendekomentasian perawatan pasien. Jakarta : EGC

Farida, Y., dan Ratnasari, N. (2014). Analisis penggunaan obat pada komplikasi sirosis hati. Jurnal Manajemen dan Pelayanan Farmasi. Vol 4. No 2. http://jurnal .ugm.ac.id/article/view

Ester, M. (2002). Keperawatan medical bedah: pendekatan sistem gastrointestinal. Jakarta : EGC

Hidayat, A.A. (2007). Metode penelitian keperawatan dan teknik analisa data. Jakarta : Salemba Medika

Hurst, M. (2016). Belajar mudah keperawatan medical bedah. Jakarta: EGC

Inayah, L. (2004). Asuhan keperawatan pada klien dengan gangguan sistem pencernaan. Jakarta : Salemba
Ignatius, D. (2010). Medikal- Sugical nursing: patient centered collaborative care. USA: ISBN

Kowalak, J. (2011). Buku ajar patofisiologi profesioanal guide to pathophysiology (Andry, $\mathrm{H}$. penerjemah). Jakarta: EGC

Lewis, S.L. (2007). Medikal-Sugical nursing: assessment and management of clinical problems. USA: ISBN

Ndraha, S., dan Simadibrata, M. (2012). Improvement of Nutritional Status in Liver Cirrhotic Patients with Adequate Dietary Feeding and High Branched-chain Amino Acids Supplementation di Rumah sakit Dr. Cipto Mangunkusumo. Journal of Gastroenterology, Hepatology and Digestive Endoscopy Vol 3. No. 2.

http://media.neliti.com/publications

Nettina, S. (2002). Pedoman praktik keperawatan. Jakarta : EGC

Price, S.A., dan Wilson, L.M. (2006). Patofisiologi : konsep klinis prosesproses penyakit. Edisi 6. Jakarta : EGC

Potter \& Perry. (2006). Buku Ajar Fundamental Keperawatan : konsep, proses dan praktik, Vol, 2. Jakarta : EGC

Smeltzer, S. (2010). Buku ajar : keperawatan medical. Jakarta : EGC

Virgonita, S., dan Zulkarnain, K.A. (20i2). Pola penggunaan obat pada pasien sirosis hati di Instalasi Rawat Inap Bangsal Penyakit Dalam Rumah Sakit Dr. Sardjito Yogyakarta. Journal Majalah Farmasuetik, Vol. 8 No. 3. http://jurnal. ugm.ac.id/article/view 